\title{
Axes of relationship value between manufacturers and retailers
}

\author{
Alfonso Ruiz-Martinez \\ Marketing, Universitat de Valencia Facultat d'Economia, Valencia, Spain, and \\ Irene Gil-Saura and Marta Frasquet \\ Marketing, University of Valencia, Valencia, Spain
}

\begin{abstract}
Purpose - The purpose of this paper is to define the relationship strategy of manufacturers with their retail customers through the identification of axes for the creation of relationship value.

Design/methodology/approach - A survey was carried out and 219 valid questionnaires were completed and returned by the purchasing managers of retail companies in the furniture sector. The model was estimated using the partial least squares approach.

Findings - The results revealed three axes of value creation: the core axis, the information and communication technologies (ICTs) axis, and the access axis. These axes included the benefits and costs related to the product and the service provided, the ICTs of the manufacturing project, and the relationships with the sales personnel.

Research limitations/implications - Due to the size of the sample, the authors were unable to analyse the potential unobserved heterogeneity of the sample. The authors would suggest that this aspect should be analysed in future research in order to attempt to segment clients.

Practical implications - Seller support is the main element of value creation. The importance of the efforts made by management to strengthen the capacities of the field force may be highlighted.

Originality/value - The main contribution of this study has been to increase the level of abstraction of the study of relationship value through the identification and modelling of its axes of creation for the under-researched retailers-suppliers relationship.
\end{abstract}

Keywords ICT, Product quality, Relationship value, Customization, Relational benefits, Relational costs Paper type Research paper

\section{Introduction}

Many of the exchanges between manufacturers and retailers in the distribution channel are intended to be permanent. The collaboration processes between the partners in such an exchange are established with a view to improving results. Specifically, their needs must be accommodated through joint activities in which information, routines, plans or costs are shared.

Manufacturers pursue strategies that enable them to offer more value to their customers, through strong relationships with the latter, and thus ensure products are correctly positioned in stores. To achieve this, manufacturers must be able to implement strategies that allow their retail clients to achieve their objectives (Tuli et al., 2007). These strategies are based mainly on operational processes, in which the tasks related to the activities of manufacturing projects are executed (Richey et al., 2012), and are influenced, in turn, by the retailer-consumer relationship, requiring manufacturers to adapt their offers according to end customers' needs. Retail clients evaluate manufacturers' offers based on the perceived benefits and sacrifices they will obtain from such relationships. The more positive that perception is, the more likely it is that the manufacturer will become a regular supplier (Ulaga and Eggert, 2006).

From the academic standpoint, perceptions regarding the exchange of benefits and sacrifices in the relationship with a supplier are studied from the perspective of relationship value. The manufacturer acts as a value facilitator in the client's processes (Grönroos, 2008; 
Grönroos and Helle, 2010) in a scenario in which the power of retailers is increasing (Dawar and Stornelli, 2013; Kim et al., 2015). However, existing research is insufficient when it comes to recognising what dimensions integrate the manufacturer's relationship value offer.

Thus, the main objective of this study is therefore to identify the axes of value creation in the manufacturer-retailer relationship based on the analysis of relational benefits and sacrifices. Although this research question remains unanswered, certain interorganisational studies do implicitly reflect the tendency to group - at a higher level - the different benefits and sacrifices/costs that clients obtain from such relationships (e.g. Walter et al., 2001; Anderson and Narus, 2004; Ulaga and Eggert, 2006). Thus, our research furthers knowledge in an area of great interest for researchers and professionals (Ulaga and Eggert, 2006; López Sánchez et al., 2012).

The relationship between manufacturers and retailers is basically subject to a series of processes that take place from the moment the retail store contacts the manufacturer until it receives the order. In each of these processes the customer perceives a series of relationship benefits and sacrifices. In this sense, the literature recognises the benefits and costs deriving from the product/service or from the manufacturer's main activity itself (e.g. Ulaga and Eggert, 2006; Barry and Terry, 2008; Kelly and Scott, 2011; López Sánchez et al., 2012; Tang and Hsu, 2015), from the more personal interactions between buyer and seller (Price and Arnould, 1999), from the logistics service itself in the improvement of key activities such as storage, transport and distribution (Audy et al., 2012), or from the use of information and communication technologies (ICTs) in these operational processes (Perego et al., 2011; Fuentes-Blasco et al., 2017). Following this line of research, the main contribution of this study is the definition of a model for measuring relationship value between manufacturers and retailers, determining the integral dimensions based on benefits and costs.

To achieve the foregoing, the paper has been structured as follows. The first section outlines the conceptual framework that enables the axes and dimensions of relationship value to be identified. This is followed by a description of the research methodology applied through a structured questionnaire presented to retail stores in the Spanish furniture sector. The empirical results would allow us to define the relationship value measurement model. The paper concludes with an analysis of final results and conclusions.

\section{Theoretical framework}

In recent years, one of the main challenges has been to come up with an accurate conceptual definition of relationship value. The study by Moliner-Velazquez et al. (2014) compiles the main contributions from literature, showing that the most widely accepted definition has been the one proposed by Eggert and Ulaga. According to these authors, relationship value is considered to be "[...] the trade-off between benefits and sacrifices perceived by the customer in a supplier's offering" (Eggert and Ulaga, 2010, p. 1347). The review of the literature revealed that the identification of the dimensions of relationship value and their influence on variables of a behavioural nature has been a recurring concern among researchers (see Table I). However, despite the efforts made, no consensus has yet been reached on its nature and structure.

Regarding the identification of the dimensions of relationship value, these tend to encompass the benefits and sacrifices/costs associated with the relationship. However, the lack of a homogeneous definition of these dimensions in the bibliography, results in a high level of abstraction of relationship value. Thus, the literature tends to attribute different meanings to different benefits and costs depending on whether they refer to functional areas (e.g. Walter et al., 2001), aspects of value (Anderson and Narus, 2004) or sources of value creation (e.g. Ulaga and Eggert, 2006). Despite these plausible initiatives, focussed on the supplier-industrial manufacturer relationship, no progress has been made in the proposal of 


\begin{tabular}{lll}
\hline Author & Aim & Methodology \\
\hline $\begin{array}{l}\text { Lapierre } \\
(2000)\end{array}$ & $\begin{array}{l}\text { Analyse relationship value } \\
\text { structure in industrial service } \\
\text { firms }\end{array}$ & $\begin{array}{l}209 \text { and } 129 \\
\text { purchasing } \\
\text { managers in the } \\
\text { Canadian } \\
\text { technological and } \\
\text { financial industries }\end{array}$ \\
$\begin{array}{ll}\text { Cannon and } \\
\text { Homburg } \\
(2001)\end{array}$ & $\begin{array}{l}\text { Study value creation from cost } \\
\text { reduction to customer firms }\end{array}$ & $\begin{array}{l}\text { purchasing } \\
\text { managers in EEUU } \\
\text { and Germany }\end{array}$
\end{tabular}

Walter et al. Determine relationship quality (2003) antecedents

Kumar and Explore new relational benefits Grisaffe and analyse their effects on (2004) quality-value-intention model

Ulaga and Identify relationship value Eggert dimensions (2006)

Barry and Determine value antecedents Terry (2008) and outcomes $\begin{array}{ll}\text { Olaru et al. } & \begin{array}{l}\text { Analyse value determinant } \\ \text { (2008) }\end{array} \\ \text { factors in R\&D industry }\end{array}$

Cater and Analyse customer's satisfaction 477 purchasing Cater (2009) and loyalty

Scheer et al. Examine if supplier capabilities 174 purchasing (2009) impact on customer dependence managers of $\begin{array}{lll} & \text { and loyal behaviours } & \text { industrial product } \\ \text { Wagner } & \text { Examine the relationship } & 186 \text { purchasing }\end{array}$ et al. (2010) between value creation and value appropriation

Cheung Investigate relational

et al. (2010) knowledge effects on relationship value

Callarisa Investigate how functional or Fiol et al. rational aspects and emotional (2011) or social aspects affect perceived value

Hutchinson Solve modelling differences of et al. (2011) behavioural intentions managers

Relevant variables analysed

Alternative solutions, product quality, customization, responsiveness, flexibility, reliability, technical competence, image, trust, solidarity, price, effort, conflict

Direct costs, acquisition costs, operation costs, supplier communications,

supplier accommodation, supplier characteristics, customer cost management, market and positional controls, customer continuity intention Direct relational functions, indirect relational functions, relationship quality, availability of alternative suppliers Industry leadership, innovation, perceived price, customer focus, perceived quality, customer value, behavioural intention office products firms 288 purchasing managers of manufacturing firms in USA

202 industrial purchasing managers in service industries 918 customers in $\mathrm{I}+\mathrm{D}$ industry managers in Germany and Switzerland 126 purchasing managers of four different industries

101 purchasing managers in the Spanish ceramic floor tile industry 159 purchasing managers of three different industries
Relationship benefits: core offering, sourcing process, customer operations; relationship costs: direct costs, acquisition costs, operation costs; relationship costs

Relationship benefits, relationship costs, relationship value, affective commitment, behavioural intentions

Relationship benefits, service benefits, monetary sacrifices, value, behavioural intentions

Direct costs, core offering, customer operations, process sourcing, satisfaction and loyalty

Core offering, communication, operations, dependence, loyalty

Trust, satisfaction, value, information exchange, future collaboration

Environmental factors, interorganizational factors, cultural distance, relationship learning, relationship value

Product quality, service quality, sacrifices, social value, and emotional value

Behavioural intentions, relationship quality, relationship benefits, relationship sacrifices
Table I.

Summary of empirical studies of business-to-business relationship value relationship value

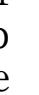




\begin{tabular}{|c|c|c|c|}
\hline Author & Aim & Methodology & Relevant variables analysed \\
\hline $\begin{array}{l}\text { Blocker } \\
\text { (2011) }\end{array}$ & $\begin{array}{l}\text { Model value perceptions of } \\
\text { intercultural customer }\end{array}$ & $\begin{array}{l}800 \text { purchasing } \\
\text { technological } \\
\text { managers }\end{array}$ & $\begin{array}{l}\text { Offer quality, personal interaction, } \\
\text { service support, know-how, direct costs, } \\
\text { acquisition costs, operation costs, } \\
\text { overall satisfaction }\end{array}$ \\
\hline $\begin{array}{l}\text { O'Cass and } \\
\text { Ngo (2011) }\end{array}$ & $\begin{array}{l}\text { Model firms' performance } \\
\text { through value offering and } \\
\text { outcomes achieved }\end{array}$ & $\begin{array}{l}301 \mathrm{CEOs} \text { of } \\
\text { Australian firms }\end{array}$ & $\begin{array}{l}\text { Value offering, value proposition, } \\
\text { customer perceived value-in-use }\end{array}$ \\
\hline $\begin{array}{l}\text { Ritter and } \\
\text { Walter } \\
\text { (2012) }\end{array}$ & $\begin{array}{l}\text { Analyse relationship functions } \\
\text { impact on relationship value }\end{array}$ & $\begin{array}{l}112 \text { German } \\
\text { purchasing firms }\end{array}$ & $\begin{array}{l}\text { Change-related relationships functions, } \\
\text { Operation-related relationship functions, } \\
\text { customer innovativeness, value }\end{array}$ \\
\hline $\begin{array}{l}\text { Hultén } \\
\text { (2012) }\end{array}$ & $\begin{array}{l}\text { Analyses customers' value } \\
\text { perceptions of the value of } \\
\text { upgraded product offerings }\end{array}$ & $\begin{array}{l}93 \text { managers in the } \\
\text { Swedish business- } \\
\text { to-business sector }\end{array}$ & $\begin{array}{l}\text { Communication, usage situations, } \\
\text { operative value drivers }\end{array}$ \\
\hline $\begin{array}{l}\text { Ye and } \\
\text { Zhang } \\
\text { (2013) }\end{array}$ & $\begin{array}{l}\text { Analyse competitive } \\
\text { differentiation through specific } \\
\text { value }\end{array}$ & $\begin{array}{l}329 \text { business } \\
\text { industrial } \\
\text { managers }\end{array}$ & $\begin{array}{l}\text { Capital, human resources, hardware } \\
\text { circumstance, information platform, } \\
\text { technology, skill }\end{array}$ \\
\hline $\begin{array}{l}\text { Song et al. } \\
\text { (2016) }\end{array}$ & $\begin{array}{l}\text { Investigate the linkages } \\
\text { between strategic interaction } \\
\text { and relationship value }\end{array}$ & $\begin{array}{l}120 \text { customer firm } \\
\text { managers }\end{array}$ & $\begin{array}{l}\text { Product-based services, integrated } \\
\text { managerial services, strategic } \\
\text { interaction, relationship value }\end{array}$ \\
\hline $\begin{array}{l}\text { Cui and } \\
\text { Coenen } \\
(2016)\end{array}$ & $\begin{array}{l}\text { Examine the relation between } \\
\text { relationship value and } \\
\text { relationship quality }\end{array}$ & $\begin{array}{l}60 \text { senior managers } \\
\text { of customers' firms }\end{array}$ & $\begin{array}{l}\text { Service quality, service support, } \\
\text { delivery, direct costs, process costs, } \\
\text { sustainability, and others }\end{array}$ \\
\hline
\end{tabular}

Table I.

Source: Own elaboration

a comprehensive measurement of relationship value based on its constituent dimensions. We therefore decided to conduct a more in-depth study of this theoretical framework through the establishment of a structure for the measurement of relationship value that would allow us to classify the different dimensions identified in the literature. Thus, in order to establish the dimensional structure of relationship value between manufacturer and retailers based on the main benefits and sacrifices/costs, our proposal was based on three axes: dimensions that are considered essential in relationships between manufacturers and supplier companies or customers (core axis); dimensions that are related to the manufacturer's sales staff (access axis); and dimensions related to the use of technologies (ICT axis). These three potential axes of value creation are developed below.

\subsection{Core axis of relationship value}

The proposals identified in the literature tend to highlight benefits and sacrifices/costs that have the most weight in the study of relationship value. This suggested that in any value proposition, there will be a series of relationship benefits and costs that could be deemed essential. The core benefits mentioned in literature are the following: product quality (Ulaga and Eggert, 2006), or the degree to which a good is adapted to a customer's operations; order delivery (Kujala et al., 2013; Ulaga and Eggert, 2006), or the degree to which the manufacturer believes that it has satisfied the customer's expectations, usually defined based on two components - the result of the service and the service process; and, finally, the benefit resulting from personnel training (Ulaga and Reinartz, 2011), necessary in any innovation-oriented company and which is based on knowledge and experience.

The main sacrifices/costs highlighted in literature are: product cost (Grönroos and Helle, 2012), which reflects the financial aspect of the relationship and includes the service costs associated with the product; and, switching cost (Barry and Terry, 2008) or the opportunity cost associated with termination of the relationship with the manufacturer. 


\subsection{Access axis of relationship value}

The access axis takes into account all those benefits and sacrifices/costs deriving mainly from the service provided by the retail client's front-line staff. In terms of the access benefits, we may highlight customization (Franke et al., 2009) as a response to the heterogeneity of demand; in this sense, clients are more responsive to the relationship when presented with customised offers. Second, service support (Ulaga and Eggert, 2006), which is reflected through four behaviours on the part of the manufacturer linked to its responsibility in the dissemination of information, the capacity to transmit that information, the association of operations between manufacturers and customers, and adaptive sales. Third, social support (Ulaga and Eggert, 2006) would encompass the development of links that improve problem solving and promote communication, and it is associated with the prestige of working with a specific exchange partner and would also include the seller's aversion to risk (Wang et al., 2012).

In terms of access costs, the following may be identified: service failure cost (Lii et al., 2012; Harrison-Walker, 2012) deriving from the manufacturer's inability to meet customer expectations; low interaction cost (Homburg et al., 2011), stemming from imbalances between the interests and actions of the manufacturer's communication systems, namely task or interaction; and low quality cost (Yang, 2008; Cheah et al., 2011), which is the difference between the actual cost of the product/service and the cost that would be incurred if the product/service were not defective.

\subsection{ICT axis of relationship value}

Finally, the benefits associated with ICTs used in the relationship derive from the following: transportation management (Perego et al., 2011; Chalotra, 2016), where ICTs are helpful for planning, executing, tracking and measuring the transport of orders between manufacturers and retailers; field force automation (Perego et al., 2011; Berisha Qehaja et al., 2016), which allows the effectiveness of activities developed by the field force to be improved; supply chain execution, which involves real-time coordination and management enhanced by ICTs (Perego et al., 2011; Shin et al., 2012); and, finally, fleet and freight management (Perego et al., 2011), where ICTs improve fleet and freight tracking.

In terms of the costs deriving from the implementation of ICTs in a relationship, we identify: the economic cost of using ICTs and the communication process itself (Thun, 2010; Nurmilaakso, 2014); the time cost related to the implementation and obsolescence of a technology (Xie et al., 2016); the adaptation cost, or the loss of experience in the use of a new technology (Kuusi, 2015); and, the incompatibility cost, or the impossibility of using a certain technology along the supply chain (Nurmilaakso, 2014).

For summary purposes, Table II presents the proposed dimensional structure for the study of relationship value based on the three postulated axes of value creation, with their respective relationship benefits and costs for manufacturers and retailers.

\begin{tabular}{llll}
\hline & Core axis & Access axis & ICT axis \\
\hline \multirow{2}{*}{ Benefits } & Product quality & Customization & Transportation management \\
& Order delivery & Service support & Field force automation \\
& Personnel training & Social support & Supply chain execution \\
& & Service failure cost & Fleet and freight management \\
Costs & Product cost & Low interaction cost & Time cost \\
& Switching cost & Low quality cost & Adaptation cost \\
& & & Incompatibility cost
\end{tabular}




\section{Research methodology}

In order to define the manufacturer's relationship strategy with its retail clients through the creation of relationship value, we designed a questionnaire to capture the three defined axes (core, access, and ICTs) and 19 dimensions that provided them with content.

The technical details of the research are shown in Table III.

\subsection{Measurement instrument}

In all cases, the review of the literature substantiated the measurements of the constructs to be measured. Thus, product quality (Ulaga and Eggert, 2006), order delivery (Ulaga and Eggert, 2006) and personnel training (Conca et al., 2004), as benefits of the core axis, were measured based on existing scales adapted accordingly to our study context, as well as product cost (Ritter and Walter, 2012) and switching cost (Barry and Terry, 2008). For the access axis, the measures for the benefits of customization (Homburg et al., 2011), service support (Ulaga and Eggert, 2006) and social support (Wang et al., 2012), together with service failure cost (Lii et al., 2012) and low interaction cost (Homburg et al., 2011) incorporated indicators with minor adaptations of existing scales. The same did not occur in the case of "low quality cost" construct, which we developed based on the work of Yang (2008). Finally, with regard to the development of measures related to the benefits and costs of the ICT axis, the lack of validated scales in previous studies prompted us to develop our own proposal based on a review of the literature (Perego et al., 2011; Richey et al., 2012; Nurmilaakso, 2014; Kuusi, 2015). Table IV shows the wording of the items used in the questionnaire.

\subsection{Sample and data collection}

Data were collected using a structured questionnaire to measure the retail clients' perceptions of the offers from their main suppliers, following the standard method for gathering information in this type of study (e.g. Kim et al., 2012; Ritter and Walter, 2012) (see Table I). The items associated with the retained constructs were evaluated using a five-point Likert scale, in which respondents were asked about their level of agreement with each of the sentences (from "strongly disagree" to "strongly agree"). The questionnaires were administered by e-mail following the methodology proposed by O'Cass and Ngo (2011), inviting respondents to complete an on-line questionnaire, with telephone follow-up of field work.

Our study is based on the furniture industry because its importance in terms of employment and number of firms. In a durable goods industry such as furniture, the relationships among firms are characterised by a strong service component that offers increased opportunities for value creation (Steiner et al., 2016). We focussed on retail companies in the distribution channel. The furniture retail sector, according to the National Institute of Statistics (INE, 2016), represents 14 per cent of total retail firms. By choosing these companies, we were able to analyse retail clients' perception of the manufacturing projects for their orders, covering all the proposed dimensions of relationship value.

Table III.

Technical details of the research
Furniture retailers

Spain

219

Structured questionnaire to purchasing managers

May-June 2015

Exploratory factor analysis, Structural equation modelling, CTA analysis SmartPLS (3.2.1) 
Product quality

\section{PQ1}

PQ2

PQ3

PQ4

Order delivery

OD1

OD2

Personnel training

PT1

PT2

PT3

Product cost

PC1

PC2

Switching cost

$\mathrm{SC} 1$

$\mathrm{SC} 2$

$\mathrm{SC} 3$

Customization

C2

C3

Social interaction

SSI1

SSI2

SSI3

ICT benefits

TM1

TM2

TM3

FFA1
Compared with another supplier, our main supplier offer us a higher product quality

Compared with another supplier, our main supplier meets our quality standards better

Compared with another supplier, our main supplier's products are more reliable

Compared with another supplier, our main supplier offer us less variations in product quality over time

Compared with another supplier, our main supplier performs better delivery times

Compared with another supplier, deliveries from our main supplier are more accurate (no missing or wrong parts)

Many of the employees of our main supplier have enough knowledge of our sector

Employees of our main supplier possess an accurate training to understand their company's performance Our main supplier's sellers know the basic processes in product/service creation

Our main supplier offers us a cheaper procurement of the products delivered

Our main supplier offers us lower purchasing prices

It would be very time-consuming to change the supplier in this moment

Switching to another supplier will involve great risk Changing our main supplier will be too disruptive for our business, so we continue working with this one

Our main supplier's products and services are highly adapted to our needs

The major characteristics of our main supplier's products are highly adjusted to our needs

I like my main supplier seller talk about private issues with me

I like my main supplier seller try to establish a more personal relationship with me

My main supplier seller is interested by my personal situation

ICT allows my main supplier to improve the resources available

ICT allows my main supplier to reduce the existing difference between order delivery time and invoice reception time

ICT allows my main supplier to notify me precisely in any delay or problem with my order

ICT allows my main supplier to increase the efficiency in operations - i.e. online order deliveries, duplicated invoices waiting time, paper reduction, etc.
Item loading CR AVE $\alpha$

$\begin{array}{lll}0.92 & 0.73 & 0.88\end{array}$

0.85

0.92

0.91

0.73

$\begin{array}{lll}0.92 & 0.84 & 0.82\end{array}$

0.92

0.92

$0.91 \quad 0.77 \quad 0.85$

0.82

$\begin{array}{lll}0.82 & 0.71 \quad 0.68\end{array}$

0.98

0.67

$\begin{array}{lll}0.89 & 0.73 \quad 0.82\end{array}$

0.89

0.88

0.78

$\begin{array}{lll}0.94 & 0.88 & 0.87\end{array}$

0.93

0.95

$\begin{array}{lll}0.90 & 0.74 & 0.83\end{array}$

0.88

0.87

$\begin{array}{lll}0.89 & 0.5 & 0.85\end{array}$

0.72
Axes of
relationship
value 
SCE2 and reviewing invoices - electronic invoice ICT allows my main supplier to be more efficient in its operations - i.e. tracking orders, sending documentation, etc.

FFM1

ICT allows my main supplier to group orders received within a few days to avoid more transportation costs

It is necessary lot of time to implant my main supplier's technology

TC2 The obsolescence risk that I perceive from my main supplier's technology is high

$\mathrm{AC1}$ The updating cost of technology used in my

IC1 communications with my main supplier is high The rest of suppliers do not use the same technology that I need to set up in the relationship with my main supplier

IC2

My main supplier's technology is not compatible with my systems

Low quality cost LQC1

LQC2

LQC4

Seller support

SS1

SS2

SocS1

$\mathrm{SFC} 2$

$\mathrm{SFC} 3$

LIC4
The level of instructions for using products delivered by our main supplier in not accurate in comparison with other suppliers

The product packing of our main suppliers is not enough in comparison with other suppliers The number of errors/fails in products received by our main supplier are higher in comparison with other suppliers provide us with better services Compared to another supplier, our main supplier is more available when we need information

In a problem, our main supplier's selling staff try to avoid being unpleasant with us

My main supplier is fair when compensating me for a service fail

My main supplier has fair policies and practices for dealing with problems

I need my interactions with my main supplier as efficient as possible
0.07
$2.06^{* *}$

$2.02 * *$

$5.75^{* * *}$

$2.75^{* *}$

$1.90^{*}$

$3.91^{*}$

$3.20^{* * *}$

$2.83^{* *}$

1,18

Table IV.

Notes: CR, Composite reliability. For two-tailed tests: *1.65 (10 per cent significance level); **1.96 (5 per cent significance level)

The sample was made up of retailers with ICT infrastructures (such as a network-based supply or sales system).

The key informants were purchasing managers. One informant was designated per company, except in the case of large companies, in which each area manager was selected as the key informant. The questionnaire was pre-tested using 20 sample units. First, the marketing manager of a furniture manufacturer submitted the questionnaire to five retail customers to get first-hand opinions. Second, a revised version of the questionnaire 
was pilot tested with 20 firms. As a result we made some changes to the questionnaire such as rewording some items to make them shorter and avoiding or clarifying technical jargon (relating to technology). These changes resulted in an improved understanding of the questionnaire. Once the final questionnaire had been defined, 2,250 e-mails were sent out. A total of 255 responses were received, of which 219 were completed correctly, yielding a response rate of 9.6 per cent. In total, 47 per cent of the sample comprised small family businesses with a single store, while the remaining 53 per cent corresponded to business corporations with an average annual turnover of 1,055,891 euros and an average of eight employees.

\section{Results}

In order to achieve our research objective, it was necessary to design a model of first and second-order constructs of relationship value. This procedure was carried out using the partial least squares (PLS) approach following the practice of previous studies (e.g. Ulaga and Eggert, 2006; Wagner et al., 2010; Cheung et al., 2010; Hutchinson et al., 2011; Blocker, 2011; O'Cass and Ngo, 2011; Ye and Zhang, 2013; Cui and Coenen, 2016). This approach requires to adopt the two-stage modelling method (Becker et al., 2012). For that purpose, the PLS approach first estimates the scores of the first-order constructs. These scores are then used as indicators of higher-order latent variables in a subsequent analysis. This allows us to establish the high-order nature of relationship value (Becker et al., 2012). One aspect that has been debated extensively in the literature in recent years is the reflective vs formative condition of the variables analysed (Diamantopoulos, 2010). Generally speaking, authors tend to consider first-order relationship value constructs as reflective and second-order constructs as formative (e.g. Lin et al., 2005; Ulaga and Eggert, 2006; Barry and Terry, 2008). However, the specification of a relationship value measurement model must ensure that the causal relationship is correct (Diamantopoulos, 2010). Our proposal aimed to shed light on this discussion, also considering relationship value as a third-order formative construct. Thus, we are able to develop the definition of relationship value, which consisted of a series of benefits and sacrifices as first-order constructs and three axes or relationship value as second-order constructs.

\subsection{Validity of reflective constructs}

The first step in the determination of the factorial structure of relationship value consisted of an exploratory factor analysis. This analysis determined the first-order factors or dimensions of relationship value, since although we based our approach on a theoretical conception of the composition of the value axes, this factorial structure had not been previously verified in the literature. The results showed that 13 factors accounted for 69 per cent of the variance. These factors corresponded in large part to the theoretically proposed dimensions of value, with a few exceptions, such as a new factor created from item GT2, namely "the ICTs of my main supplier allow me to know the results for the delivery of goods". The number of dimensions in the Access axis and the ICT axis was reduced from the initial theoretical conception, and some dimensions appear with a new meaning, i.e. seller support has a wider meaning than social support, and social interaction is a factor derived from the theoretical low interaction factor, which has a more restricted meaning than social support. Thus the results of our empirical analysis suggest changes in the theoretically derived dimensionality of relationship value (shown in Table II), that become evident in Table IV. The final analysis based on the composite reliability index, Cronbach's $\alpha$ and average variance extracted (AVE) showed that all the constructs complied with the reliability and convergent validity requirements (see Table IV).

In terms of discriminant validity, we followed the proposal of Fornell and Larcker (1981) who suggest that the AVE index of a construct must be greater than its variance 
shared with other constructs of the model. Analysing Table V, it can be observed that discriminant validity was satisfactorily fulfilled for all the constructs of the measurement model.

\subsection{Validity of formative constructs}

The formative constructs required a different criterion in the evaluation of reliability and validity. In our study, low quality cost and seller support were considered formative constructs because they included indicators that reflected different dimensions of the same phenomenon (Wilson et al., 2007). To analyse the validity of these two formative constructs, three steps were taken: indicator relevance, indicator significance and multi-collinearity. Table IV shows the weight and level of final significance of each item in the corresponding formative construct.

\subsection{Confirmatory tetrad analysis (CTA)}

To guarantee the formative-reflective nature of the first and second-order constructs, the CTA-PLS analysis proposed by Gudergan et al. (2008) was applied. The CTA analysis considers the difference of the product of a pair of covariances with another pair of covariances of the indicator variables (tetrad) for all the converging tetrads of the measurement model. According to Gudergan et al. (2008), the significance of the statistic (i.e. the confidence interval includes zero) of all the non-redundant tetrads of the model converging to zero provides a basis for determining the reflectivity of the measurement model.

Table VI provides the necessary empirical confidence to consider the formative mode of the measurement model for the seller support and low quality cost constructs. The results indicated that at least one of the tetrads of these constructs did not converge to 0 . Therefore, the null hypothesis referring to a reflective measure was rejected, suggesting a formative structure.

\subsection{Determination of second-order factors}

The second-order factors were determined through a second exploratory factor analysis with the scores obtained from the latent variables of the confirmatory factor analysis. The identification of these factors (see Table VII) allowed us to identify the relationship value axes. Thus, the first axis included the variables defined at the time as core variables in the relationship - product quality, order delivery and personnel training - and also included customization, seller support, low quality cost, and ICT costs. According to the results obtained, this first factor was identified as the core axis. Second, switching costs, ICT benefits and electronic delivery notification made up the so-called ICT axis. Finally, social interaction and product cost defined the access axis of relationship value.

\begin{tabular}{lcrlllllll}
\hline & PQ & IC & C & OD & PT & IB & SC & PC & SI \\
\hline PQ & 0.73 & & & & & & & & \\
IC & -0.2 & 0.58 & & & & & & & \\
C & 0.43 & -0.17 & 0.87 & & & & & & \\
OD & 0.57 & -0.13 & 0.34 & 0.82 & & & & & \\
PT & 0.5 & -0.21 & 0.41 & 0.49 & 0.85 & & & & \\
IB & 0.33 & -0.11 & 0.26 & 0.32 & 0.3 & 0.85 & & & \\
SC & 0.26 & -0.11 & 0.21 & 0.18 & 0.29 & 0.21 & 0.82 & & \\
PC & -0.06 & 0.03 & 0.14 & 0.1 & 0.1 & 0.08 & 0.03 & 0.68 & \\
SI & 0.09 & -0.06 & 0.04 & 0.11 & 0.49 & 0.14 & 0.09 & -0.07 & 0.83
\end{tabular}

Table V. Discriminant validity (Fornell-Larcker criterion)
Notes: PQ, Product quality; IC, ICT costs; C, customization; OD, order delivery; PT, personnel training; IB, ICT benefits; SC, switching cost; PC, product cost; SI, social interaction 


\begin{tabular}{|c|c|c|c|c|}
\hline \multirow[b]{2}{*}{ Low quality cost } & \multirow{2}{*}{$\begin{array}{l}\text { Model-implied non-redundant vanishing tetrad } \\
\text { 1: LQC1, LQC2, LQC3, LQC4 }\end{array}$} & \multirow{2}{*}{$\frac{\text { Bootstrap } t \text {-value }}{0.95}$} & \multicolumn{2}{|c|}{$\mathrm{Cl}^{\mathrm{a}}$} \\
\hline & & & -0.08 & 0.17 \\
\hline & 2: LQC1, LQC2, LQC4, LQC3 & 0.93 & -0.09 & 0.19 \\
\hline & 4: LQC1, LQC2, LQC3, LQC5 & 1.53 & -0.06 & 0.22 \\
\hline & 6: LQC1, LQC3, LQC5, LQC2 & 0.31 & -0.10 & 0.14 \\
\hline & 10: LQC1, LQC3, LQC4, LQC5 & 2.98 & 0.03 & 0.37 \\
\hline \multirow{35}{*}{ Seller support } & 1: SS2, SS3, SocS1, SocS2 & 4.69 & 0.06 & 0.33 \\
\hline & 2: SS2, SS3, SocS2, SocS1 & 4.75 & 0.06 & 0.33 \\
\hline & 4: SS2, SS3, SocS1, SFC1 & 2.45 & -0.02 & 0.17 \\
\hline & 6: SS2, SocS1, SFC1, SS3 & 0.21 & -0.06 & 0.07 \\
\hline & 7: SS2, SS3, SocS1, SFC2 & 2.59 & -0.02 & 0.17 \\
\hline & 10: SS2, SS3, SocS1, SFC3 & 3.03 & -0.01 & 0.18 \\
\hline & 13: SS2, SS3, SocS1, SFC4 & 3.62 & 0.01 & 0.21 \\
\hline & 17: SS2, SS3, LIC4, SocS1 & 2.72 & -0.02 & 0.18 \\
\hline & 20: SS2, SS3, SS1, SocS1 & 1.55 & -0.04 & 0.12 \\
\hline & 29: SS2, SS3, SFC3, SocS2 & 3.65 & 0.01 & 0.18 \\
\hline & 31: SS2, SS3, SocS2, SFC4 & 3.71 & 0.01 & 0.20 \\
\hline & 35: SS2, SS3, LIC4, SocS2 & 2.19 & -0.03 & 0.17 \\
\hline & 41: SS2, SS3, SFC2, SFC1 & 5.26 & 0.12 & 0.52 \\
\hline & 43: SS2, SS3, SFC1, SFC3 & 4.62 & 0.07 & 0.39 \\
\hline & 47: SS2, SS3, SFC4, SFC1 & 3.96 & 0.04 & 0.37 \\
\hline & 50: SS2, SS3, LIC4, SFC1 & 1.72 & -0.05 & 0.17 \\
\hline & 60: SS2, SFC2, SFC4, SS3 & 1.28 & -0.05 & 0.02 \\
\hline & 64: SS2, SS3, SFC2, SS1 & 2.61 & -0.02 & 0.13 \\
\hline & 66: SS2, SFC2, SS1, SS3 & 1.85 & -0.07 & 0.02 \\
\hline & 71: SS2, SS3, LIC4, SFC3 & 2.24 & -0.03 & 0.18 \\
\hline & 80: SS2, SS3, SS1, SFC4 & 2.25 & -0.03 & 0.14 \\
\hline & 91: SS2, SocS1, SocS2, SFC3 & 0.35 & -0.04 & 0.05 \\
\hline & 120: SS2, SFC2, SFC3, SocS1 & 0.36 & -0.06 & 0.07 \\
\hline & 169: SS2, SocS2, SFC2, LIC4 & 0.86 & -0.07 & 0.04 \\
\hline & 182: SS2, SocS2, SS1, SFC3 & 2.35 & -0.11 & 0.02 \\
\hline & 205: SS2, SFC1, SFC3, SFC4 & 0.12 & -0.11 & 0.12 \\
\hline & 233: SS2, SFC2, LIC4, SFC4 & 1.81 & -0.16 & 0.05 \\
\hline & 236: SS2, SFC2, SS1, SFC4 & 3.26 & -0.24 & 0.00 \\
\hline & 248: SS2, SFC3, SS1, LIC4 & 2.20 & -0.13 & 0.03 \\
\hline & 281: SS3, SocS1, LIC4, SFC1 & 0.03 & -0.06 & 0.06 \\
\hline & 324: SS3, SFC1, SFC4, SocS2 & 0.14 & -0.10 & 0.10 \\
\hline & 358: SS3, SocS2, LIC4, SS1 & 0.57 & -0.05 & 0.04 \\
\hline & 395: SS3, SFC2, LIC4, SFC3 & 1.69 & -0.14 & 0.05 \\
\hline & 434: SocS1, SocS2, SS1, SFC1 & 2.12 & -0.04 & 0.18 \\
\hline & 526: SocS2, SFC1, SFC2, SFC3 & 0.23 & -0.08 & 0.09 \\
\hline
\end{tabular}

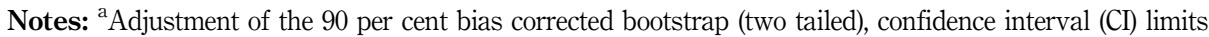
uses the Bonferroni method

Table VI. CTA-PLS results

\subsection{Structural model}

After the analysis of reliability and validity, the results obtained in phase 1 (modelling of first-order constructs) were evaluated. Bootstrapping results were achieved through 1,000 interactions. Figure 1 outlines the final significance levels of phase 1 of the modelling process after eliminating the non-significant items and constructs (product cost, SS3, SSoc2, CFS1, CFS4, CBI4, CBC3 and CBC5). This allowed us to develop further our analysis of the structural model (phase 2 of the modelling) in order to achieve our research objective. 
$\mathrm{MD}$

\begin{tabular}{lccc}
\hline Indicator & $\begin{array}{c}\text { Factor 1 } \\
\text { (Core axis) }\end{array}$ & $\begin{array}{c}\text { Factor 2 } \\
\text { (ICT axis) }\end{array}$ & $\begin{array}{c}\text { Factor 3 } \\
\text { (Access axis) }\end{array}$ \\
\hline Product quality & 0.79 & & \\
Order delivery & 0.76 & & \\
Personnel training & 0.63 & & \\
Customization & 0.59 & & \\
Low quality cost & -0.75 & & \\
Seller support & 0.64 & 0.4 & 0.62 \\
ICT costs & -0.38 & 0.75 & 0.78 \\
Switching cost & & & 9.04 \\
ICT benefits & & & \\
Electronic delivery notification & & 9.74 & \\
Social interaction & & & \\
Product cost & 34.3 & & \\
Variance extracted (\%) & & &
\end{tabular}

In this second phase, the structural model was studied through the analysis of $\beta$ coefficients. These represented the path coefficients or standardized regression weights (see Table VIII). Thus, we were able to definitively identify the composition of the three axes of relationship value, namely: core, access, and ICTs.

The core axis had a strong and positive influence on relationship value $(\beta=0.82)$. This value creation axis included, as an essential element, seller support $(\beta=0.47)$ and to a lesser extent, product customization $(\beta=0.18)$, product quality and low quality $\operatorname{cost}(\beta=0.17$ and $\beta=-0.17$, respectively). Other factors, associated with the core axis and which were analysed in our study, were not significant. This was the case of ICT costs, order delivery and personnel training.

The ICT component constituted the second axis of relationship value creation as indicated by its weight $(\beta=0.25)$. The results at ICT axis level highlighted the great importance of ICT benefits, electronic delivery notification and switching cost in the creation of value ( $\beta=0.46, \beta=0$, and $\beta=0.48$, respectively).

In terms of the access axis, the results reflected its positive, albeit smaller than the other two axis', influence on value creation $(\beta=0.14)$. This relationship value axis was subordinated to the social interaction of the relationship.

\section{Conclusion}

This study allowed us to define a dimensional structure of relationship value in the relations of manufacturers with retailers based on a review of the literature and the results of an empirical study.

\subsection{Academic implications and practices}

The identification of the factors that determine long-term business relationships is considered essential in marketing (Ulaga and Eggert, 2006). Our study was based on a line of research proposed in benchmark studies on value (e.g. Ulaga and Eggert, 2006; Barry and Terry, 2008; López Sánchez et al., 2012; Ritter and Walter, 2012) characterised by the tendency to classify the dimensions of value creation at a higher level. However, unlike the aforementioned studies that model value as a one-dimensional construct, we adopted a multi-dimensional research approach in which value was defined as a third-order formative construct (e.g. Lin et al., 2005; O'Cass and Ngo, 2011; Biggemann and Buttle, 2012). In this sense, our research contributes to the establishment of value creation axes and the dimensions of each of these axes in the context of relations between manufacturers and retailers. 


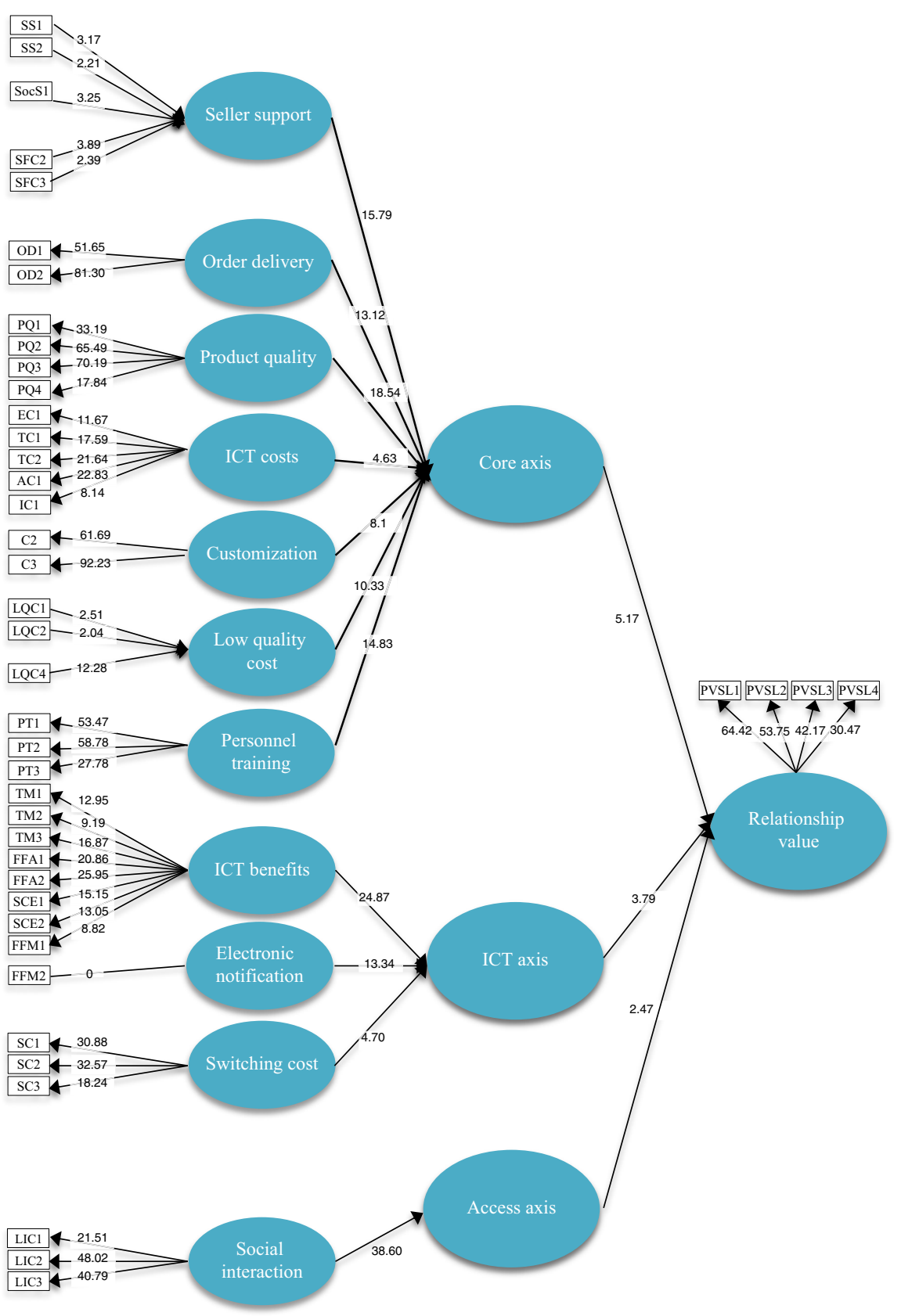




\begin{tabular}{lc} 
& $\beta$ \\
\hline Product quality $\rightarrow$ core axis & $0.17^{*}$ \\
Low quality cost $\rightarrow$ core axis & $-0.17^{*}$ \\
ICT costs $\rightarrow$ core axis & -0.08 \\
Customization $\rightarrow$ core axis & $0.18^{* *}$ \\
Order delivery $\rightarrow$ core axis & 0.04 \\
Personnel training $\rightarrow$ core axis & 0.14 \\
Seller support $\rightarrow$ core axis & $0.47^{* * *}$ \\
ICT benefits $\rightarrow$ ICT axis & $0.46^{* * *}$ \\
Electronic delivery notification $\rightarrow$ ICT axis & $0.43^{* * *}$ \\
Switching cost $\rightarrow$ ICT axis & $0.48^{* * *}$ \\
Core axis $\rightarrow$ relationship value & $0.82^{* * *}$ \\
Access axis $\rightarrow$ relationship value & $0.14^{*}$ \\
ICT axis $\rightarrow$ relationship value & $0.25^{* * *}$
\end{tabular}

Table VIII.

ICT axis $\rightarrow$ relationship value

Stability of the results Notes: For two-tailed tests: ${ }^{*} p<0.1 ; * * p<0.05 ; * * * p<0.01$

benefits that have traditionally been considered as core benefits in such relationships (e.g. product quality). This formative construct includes aspects relating to service support, social support and service failure cost. It is therefore one of the key benefits in the manufacturer's offer associated with the marketing of a product. In this sense, it has also been shown that product individualisation or customization is a core component of value; this result may be attributed to the durable products sector in which our research was carried out.

The ITC axis is related to the benefits of ICTs and supplier switching cost. On this point, one of the most valuable aspects of our research was the introduction of ICTs in the measurement model through their relationship benefits and costs. In particular, our study highlights the ICT benefits deriving from the optimisation of merchandise logistics. These benefits were significant, contrasting with the results for delivery service, and therefore constitute an element of differentiation in the manufacturer's offer. All those benefits associated with the automation of field force tasks were also included; these improve the manufacturer's communication capabilities with respect to the retail client. Finally, the benefits deriving from the execution of the supply chain and the benefits of transport management allow manufacturing projects to be monitored in real time, reducing the lead times that manufacturers need to report on the status and delivery of retailer's orders. In terms of ICT sacrifices, the results highlighted switching cost. In our study, switching cost was not a dimension of the core axis in the creation of value. Similar studies (e.g. Barry and Terry, 2008) identified this as one of the most important relational costs in the creation of value. This discrepancy in the results may be due to the fact that in the manufacturer-supplier relationship, switching cost relates to changing the production value chain, whereas in the retailer-manufacturer relationship that we analysed, switching costs are related to a change in the assortment, and this decision would balance the benefits and costs of the relationship.

Finally, the access axis highlighted the importance of social interaction in the relationship. In contrast, product cost, which has been highlighted in similar studies (e.g. Ulaga and Eggert, 2006; Ritter and Walter, 2012) in the creation of relationship value, was not significant in our study. In this connection, some authors, such as Grönroos and Helle (2012), mention payment function as the main dimension of the core axis of relationships. This suggests that the more relational the exchange, the lesser the potential importance of price in the manufacturer's relational strategy. In this industry most of the suppliers offer similar prices, thus product cost may not be a differentiating factor that 
creates value, when compared with service-related factors (Steiner et al., 2016). Thus, we conclude that relationship value is built with different blocks in industrial relationships and in commercial relationships.

The results of this study also provide a series of practical implications for manufacturers in the quest to create more value from their relationships with their retail clients. First, our results showed that variables such as product cost or order delivery, traditionally considered essential in the creation of value, have no effect on the creation of relationship value. For this reason, we may highlight the importance of updating the basis on which a manufacturer's relational strategy is based. On this point, the establishment of seller support shows manufacturers the importance of having sales managers capable of providing a good service to retail clients and of giving feedback to the organisation on new opportunities for improvement. Second, the introduction of ICTs in the relationship with retailers is no longer an option in the manufacturer's relational strategy. Specifically, the empirical evidence obtained in our study allowed us to identify the most effective operations in manufacturing processes for creating value. However, in order to benefit retail clients, investment actions undertaken by manufacturers must minimise the economic cost of implementing the technologies in question and maximise the value of such investments for all their retail clients.

\subsection{Limitations and future research}

This study has certain limitations that may impact the results and should be addressed in future research. Our study analysed the relationship value between manufacturers and retailers in the furniture sector in Spain. In this sense, a similar study would be necessary at inter-sectoral level and in other cultural contexts in order to validate and consolidate the results obtained here.

Second, the consolidation of the definition of relationship value must be extended to incorporate other relational constructs (see Table I). Our study proposes the inclusion of the other constructs that constitute relational quality in marketing, specifically satisfaction, trust and commitment, as well as the performance of a more in-depth analysis of the establishment of the loyal behaviours.

Finally, future lines of longitudinal research are essential in order to further improve the process that generates relationship value in inter-organisational exchanges in distribution channels.

\section{References}

Anderson, J.C. and Narus, J.A. (2004), Business Market Management: Understanding, Creating, and Delivering Value, 2nd ed., Prentice Hall, Upper Saddle River, NJ.

Audy, J.F., Lehoux, N., D’Amours, S. and Rönnqvist, M. (2012), “A framework for an efficient implementation of logistics collaborations", International Transactions in Operational Research, Vol. 19 No. 5, pp. 633-657.

Barry, J. and Terry, T.S. (2008), "Empirical study of relationship value in industrial services", The Journal of Business \& Industrial Marketing, Vol. 23 No. 4, pp. 228-241.

Becker, J.-M., Klein, K. and Wetzels, M. (2012), "Hierarchical latent variable models in PLS-SEM: guidelines for using reflective-formative type models", Long Range Planning, Vol. 45 Nos 5/6, pp. 359-394.

Berisha Qehaja, A., Kutllovci, E. and Berisha Namani, M. (2016), "Improving salesperson effectiveness through sales forces automation tools in wholesale distribution firms", Poslovna Izvrsnost, Vol. 10 No. 1, pp. 99-118. 
Biggemann, S. and Buttle, F. (2012), "Intrinsic value of business-to-business relationships: an empirical taxonomy”, Journal of Business Research, Vol. 65 No. 8, pp. 1132-1138.

Blocker, C.P. (2011), "Modeling customer value perceptions in cross-cultural business markets", Journal of Business Research, Vol. 64 No. 5, pp. 533-540.

Callarisa Fiol, L.J., Moliner Tena, M.A. and Sánchez García, J. (2011), "Multidimensional perspective of perceived value in industrial clusters", Journal of Business \& Industrial Marketing, Vol. 26 No. 2, pp. 132-145.

Cannon, J.P. and Homburg, C. (2001), "Buyer-supplier relationships and customer firm costs", Journal of Marketing, Vol. 65 No. 1, pp. 29-73.

Cater, B. and Cater, T. (2009), "Relationship-value-based antecedents of customer satisfaction and loyalty in manufacturing", Journal of Business \& Industrial Marketing, Vol. 24 No. 8, pp. 585-597.

Chalotra, V. (2016), "Key processes adopted for transportation management system in small scale firms", Parikalpana: KIIT Journal of Management, Vol. 12 No. 1, pp. 1-10.

Cheah, S.J., Shahbudin, A.S.M. and Taib, F.M. (2011), "Tracking hidden quality costs in a manufacturing company: an action research", International Journal of Quality \& Reliability Management, Vol. 28 No. 4, pp. 405-425.

Cheung, M.-S., Myers, M.B. and Mentzer, J.T. (2010), "Does relationship learning lead to relationship value? A cross-national supply chain investigation", Journal of Operations Management, Vol. 28 No. 6, pp. 472-487.

Conca, F.J., Llopis, J. and Tarí, J.J. (2004), "Development of a measure to assess quality management in certified firms", European Journal of Operational Research, Vol. 156 No. 3, pp. 683-697.

Cui, Y.Y. and Coenen, C. (2016), "Relationship value in outsourced FM services - value dimensions and drivers", Facilities, Vol. 34 Nos 1/2, pp. 43-68.

Dawar, N. and Stornelli, J. (2013), "Rebuilding the relationship between manufacturers and retailers", MIT Sloan Management Review, Vol. 54 No. 2, pp. 83-90.

Diamantopoulos, A. (2010), "Reflective and formative metrics of relationship value: response to Baxter's commentary essay”, Journal of Business Research, Vol. 63 No. 1, pp. 91-93.

Eggert, A. and Ulaga, W. (2010), "Managing customer share in key supplier relationships", Industrial Marketing Management, Vol. 39 No. 8, pp. 1346-1355.

Fornell, C. and Larcker, D.F. (1981), "Evaluation structural equation models with unobservable variables and measurement error", Journal of Marketing Research, Vol. 18, pp. 39-50.

Franke, N., Keinz, P. and Steger, C.J. (2009), "Testing the value of customization: when do customers really prefer products tailored to their preferences?”, Journal of Marketing, Vol. 73 No. 5, pp. 103-121.

Fuentes-Blasco, M., Moliner-Velázquez, B. and Gil-Saura, I. (2017), "Exploring relationship variables and information and communication technologies use in industrial segmentation", Management Decision, Vol. 55 No. 7, pp. 1441-1459.

Grönroos, C. (2008), "Service logic revisited: who creates value? And who co-creates?", European Business Review, Vol. 20 No. 4, pp. 298-314.

Grönroos, C. and Helle, P. (2010), "Adopting a service logic in manufacturing: conceptual foundation and metrics for mutual value creation", Journal of Service Management, Vol. 21 No. 5, pp. 564-590.

Grönroos, C. and Helle, P. (2012), "Return on relationships: conceptual understanding and measurement of mutual gains from relational business engagements", The Journal of Business \& Industrial Marketing, Vol. 27 No. 5, pp. 344-359.

Gudergan, S.P., Ringle, C.M., Wende, S. and Will, A. (2008), “Confirmatory tetrad analysis in PLS path modeling", Journal of Business Research, Vol. 61 No. 12, pp. 1238-1249.

Harrison-Walker, L.J. (2012), "The role of cause and affect in service failure", Journal of Services Marketing, Vol. 26 No. 2, pp. 115-123. 
Homburg, C., Müller, M. and Klarmann, M. (2011), "When does salespeople's customer orientation lead to customer loyalty? The differential effects of relational and functional customer orientation", Journal of the Academy of Marketing Science, Vol. 39 No. 6, pp. 795-812.

Hultén, P. (2012), "Value creation by 'muddling' in the B2B sector", Journal of Business Research, Vol. 65 No. 6, pp. 781-787.

Hutchinson, D., Wellington, W.J., Saad, M. and Cox, P. (2011), "Refining value-based differentiation in business relationships: a study of the higher order relationship building blocks that influence behavioural intentions”, Industrial Marketing Management, Vol. 40 No. 3, pp. 465-478.

Kelly, S. and Scott, D. (2011), "Relationship benefits: conceptualization and measurement in a businessto-business environment”, International Small Business Journal, Vol. 30 No. 3, pp. 310-339.

Kim, D., Jung, G.O. and Park, H.H. (2015), "Manufacturer's retailer dependence: a private branding perspective", Industrial Marketing Management, Vol. 49, pp. 95-104.

Kim, D.-Y., Kumar, V. and Kumar, U. (2012), "Relationship between quality management practices and innovation”, Journal of Operations Management, Vol. 30 No. 4, pp. 295-315.

Kujala, J., Ahola, T. and Huikuri, S. (2013), "Use of services to support the business of a project-based firm”, International Journal of Project Management, Vol. 31 No. 2, pp. 177-189.

Kumar, A. and Grisaffe, D.B. (2004), "Effects of extrinsic attributes on perceived quality, customer value, and behavioral intentions in B2B settings: a comparison across goods and service industries", Journal of Business to Business Marketing, Vol. 11 No. 4, pp. 43-74.

Kuusi, T. (2015), "The dynamics of ICT adaptation and the productivity gaps across advanced nations", Journal of Productivity Analysis, Vol. 44 No. 2, pp. 175-188.

Lapierre, J. (2000), "Customer-perceived value in industrial contexts", The Journal of Business \& Industrial Marketing, Vol. 15 Nos 2/3, pp. 122-145.

Lii, Y., Pant, A. and Lee, M. (2012), "Balancing the scales: recovering from service failures depends on the psychological distance of consumers", The Service Industries Journal, Vol. 32 No. 11, pp. 1775-1790.

Lin, C.H., Sher, P.J. and Shih, H.-Y. (2005), "Past progress and future directions in conceptualizing customer perceived value", International Journal of Service Industry Management, Vol. 16 Nos 3/4, pp. 318-336.

López Sánchez, J.Á., Santos Vijande, M.L. and Trespalacios Gutiérrez, J.A. (2012), "Value-creating functions, satisfaction and loyalty in business markets: a categorical variable approach using a robust methodology under structural equation modeling", Quality \& Quantity, Vol. 46 No. 3, pp. 777-794.

Moliner-Velazquez, B., Fuentes-Blasco, M. and Gil-Saura, I. (2014), "Value antecedents in relationship between tourism companies”, Journal of Business \& Industrial Marketing, Vol. 29 No. 3, pp. 215-226.

Nurmilaakso, J.-M. (2014), "Coordination costs and ICT investments: an economic analysis", NETNOMICS: Economic Research and Electronic Networking, Vol. 15 No. 2, pp. 57-67.

O'Cass, A. and Ngo, L.V. (2011), "Examining the firm's value creation process: a managerial perspective of the firm's value offering strategy and performance: examining the firm's value creation process", British Journal of Management, Vol. 22 No. 4, pp. 646-671.

Olaru, D., Purchase, S. and Peterson, N. (2008), "From customer value to repurchase intentions and recommendations", Journal of Business \& Industrial Marketing, Vol. 23 No. 8, pp. 554-565.

Perego, A., Perotti, S. and Mangiaracina, R. (2011), "ICT for logistics and freight transportation: a literature review and research agenda", International Journal of Physical Distribution \& Logistics Management, Vol. 41 No. 5, pp. 457-483.

Price, L.L. and Arnould, E. (1999), "Commercial friendships: service provider-client relationships in context”, Journal of Marketing, Vol. 63 No. 4, pp. 38-56.

Richey, R.G., Adams, F.G. and Dalela, V. (2012), "Technology and flexibility: enablers of collaboration and time-based logistics quality", Journal of Business Logistics, Vol. 33 No. 1, pp. $34-49$.

Ritter, T. and Walter, A. (2012), "More is not always better: the impact of relationship functions on customer-perceived relationship value", Industrial Marketing Management, Vol. 41 No. 1, pp. 136-144. 
Scheer, L.K., Miao, C.F. and Garrett, J. (2009), "The effects of supplier capabilities on industrial customers' loyalty: the role of dependence", Journal of the Academy of Marketing Science, Vol. 38 No. 1, pp. 90-104.

Shin, K., Shin, Y., Kwon, J. and Kang, S. (2012), "Risk propagation based dynamic transportation route finding mechanism”, Industrial Management \& Data Systems, Vol. 112 No. 1, pp. 102-124.

Song, H., Yu, K., Chatterjee, S.R. and Jia, J. (2016), "Service supply chain: strategic interaction and relationship value", Journal of Business \& Industrial Marketing, Vol. 31 No. 5, pp. 611-624.

Steiner, M., Eggert, A., Ulaga, W. and Backhaus, K. (2016), "Do customized service packages impede value capture in industrial markets?”, Journal of the Academy of Marketing Science, Vol. 44 No. 2, pp. 151-165.

Tang, J.-W. and Hsu, T.-H. (2015), “A fuzzy preference relations model for evaluating key supplier relationships in TFT-LCD TV panel manufacturing industry", Management Decision, Vol. 53 No. 8, pp. 1858-1882.

Thun, J. (2010), "Angles of integration: an empirical analysis of the alignment of internet-based information technology and global supply chain integration", Journal of Supply Chain Management, Vol. 46 No. 2, pp. 30-44.

Tuli, K.R., Kohli, A.K. and Bharadwaj, S.G. (2007), "Rethinking customer solutions: from product bundles to relational processes", Journal of Marketing, Vol. 71 No. 3, pp. 1-17.

Ulaga, W. and Eggert, A. (2006), "Value-based differentiation in business relationships: gaining and sustaining key supplier status", Journal of Marketing, Vol. 70 No. 1, pp. 119-136.

Ulaga, W. and Reinartz, W.J. (2011), "Hybrid offerings: how manufacturing firms combine goods and services successfully", Journal of Marketing, Vol. 75 No. 6, pp. 5-23.

Wagner, S.M., Eggert, A. and Lindemann, E. (2010), "Creating and appropriating value in collaborative relationships", Journal of Business Research, Vol. 63 No. 8, pp. 840-848.

Walter, A., Ritter, T. and Gemunden, H.G. (2001), "Value creation in buyer-seller relationships: theoretical considerations and empirical results from a supplier's perspective", Industrial Marketing Management, Vol. 30 No. 4, pp. 365-377.

Walter, A., Müller, T., Helfert, G. and Ritter, T. (2003), "Functions of industrial supplier relationships and their impact on relationship quality", Industrial Marketing Management, Vol. 32 No. 2, pp. 159-169.

Wang, S., Beatty, S.E. and Liu, J. (2012), "Employees' decision making in the face of customers' fuzzy return requests", Journal of Marketing, Vol. 76 No. 6, pp. 69-86.

Wilson, B., Callaghan, W. and Stainforth, G. (2007), "An application of vanishing TETRAD analysis to a brand model", International Review of Business Research Papers, Vol. 3 No. 2, pp. 456-485.

Xie, Y., Breen, L., Cherrett, T., Zheng, D. and Allen, C.J. (2016), "An exploratory study of reverse exchange systems used for medical devices in the UK National Health Service (NHS)", Supply Chain Management: An International Journal, Vol. 21 No. 2, pp. 194-215.

Yang, C.-C. (2008), "Improving the definition and quantification of quality costs", Total Quality Management \& Business Excellence, Vol. 19 No. 3, pp. 175-191.

Ye, J. and Zhang, M. (2013), "Providing specific value in business markets: gaining and sustaining unique supplier status", Research Journal of Applied Sciences, Engineering and Technology, Vol. 5 No. 24 , pp. 5503-5508.

\section{Corresponding author}

Irene Gil-Saura can be contacted at: irene.gil@uv.es

For instructions on how to order reprints of this article, please visit our website:

www.emeraldgrouppublishing.com/licensing/reprints.htm

Or contact us for further details: permissions@emeraldinsight.com 